\title{
Prerogative Right of the President in Granting Pardon (Comparative Analysis on a Number of Countries)
}

\author{
Andryan $^{1}$, Eddy Purnama ${ }^{2}$, Suhaidi $^{3}$, Faisal Akbar Nasution ${ }^{4}$ \\ $\left\{\right.$ andryan@umsu.ac.id ${ }^{1}$ \} \\ Universitas Sumatera Utara, Indonesia ${ }^{1,2,3,4}$
}

\begin{abstract}
President's prerogative rights are derived from special and independent rights with-out involving other branches of power. We need to observe state administrative norms in some countries in the world relating to the president's pardon granting authority. This research applies the normative judicial method with conceptual and comparative approaches aimed to see the history and application of prerogative rights in a number of countries, especially the president's prerogative right in pardon granting. Pardon is a valid executive action to entirely or partially release the legal consequence of a guilty verdict on a criminal act committed by a person. The authority to grant clemency or pardon is often included in the scope of the king or president's prerogative rights. The involvement of other branches of power in the pardon granting mechanism shall not automatically reduce the president's power (prerogative). Almost all modern countries tend to adopt a government system that attempts to place all governance models. In some countries, the head of state's pardon power is explicitly called prerogative right, though the involvement of other branches of power remains possible in its mechanism.
\end{abstract}

Keywords: Prerogative Rights, President, Pardon, A Number of Countries

\section{Introduction}

Historically, prerogative rights, seen from the perspective of state administrative law, derived from the United Kingdom state administrative system. In the United Kingdom state administrative history, the king's power (authority) [1] actually came first compared to the parliamentary (House of Commons) sovereignty. The upheaval taking place at that time, as a resistance to the King's absolute arbitrary power, had resulted in the Revolution of 1688 and had forced the King to delegate a part of his power to the House of Commons that represents the people. The residues of such King's power are then called prerogative rights.

According to Dicey, these prerogative rights refer to the independent power residues at any time being on the King's hands, although they are exercised by the King himself or by his Ministers. Since prerogative power does not originate from or is not stipulated in the laws and regulations drawn up by the parliament, it embodies discretionary power. Another reason why prerogative power exists in the United Kingdom state administrative system is the parliamentary government system it adheres to, where there is a strict difference between the positions of the head of state and the head of government.

With the head of state position being held by the King/Queen of the United Kingdom, the principle used is king is indefeasible. This principle serves as a ground for the King/Queen of the United Kingdom to be granted prerogative power, namely the special power fully inherent 
in the King/Queen of the United Kingdom. Therefore, it is understandable that prerogative power remains available as a system in the state administration of the United Kingdom. Dicey mentioned a number of prerogative rights in the United Kingdom, such as declaring war or amicable settlement and dissolving the parliament. Meanwhile, Bagir Manan said that even though prerogative power in the United Kingdom is not an enumerative description, it comprises, among others [2]:

a. The power to mobilize the army for a war;

b. The power to enter into an international agreement and to build international relations;

c. The power to give clemency.

In the book Two Treatises of Government, John Locke revealed prerogative power as the power to undertake a discretionary act for a public interest, without observing the prevailing legal provisions, even by opposing the law itself. Locke justified that the existing laws are unable to accommodate the countless existing issues. It is even impossible to predict a law that can provide solutions to all existing public interests. Such a special power called prerogative power is therefore required. Locke further said that prerogative power is simply a power to do good (to practice virtues) virtue for the public without any law/rule.

In the governance system of modern countries, prerogative rights are owned by the heads of state (kings and presidents) and the heads of government in particular sectors declared in the constitution. An example of the exercise of these rights is when France granted prerogative right to its President to discharge the head of government and to dissolve the National Assembly following his prior consultation with the Prime Minister and the Chairmen of the National Assembly. Another example is the right of the President of the United State of America to veto the law approved by Congress. This right is also considered equivalent to the full authority granted by the constitution to an executive body within the scope of its governance authority (particularly for the system applying strict separation of powers, such as the United States of America) to establish political and economic policies.

Pardon or clemency granting has been recognized since the $15^{\text {th }}$ century, first found in French law and the Latin term perdonare (to give freedom and to represent a gift from the authority). This pardon granting continued to develop and in the $18^{\text {th }}$ century, it was known in an absolute kingdom in Europe as a gift from the king (Vorstelijke Gunst) that granted clemency to a penalized (convicted) person.

This act of clemency was based upon the king's kindness. The king was considered the source of power, including the source of justice, and the right to adjudicate was fully in the king's hands. However, following the development of modern countries, judicial power has been separated from government power due to the influence of the Trias Politica concept, which prohibits the arbitrary interference of the government power in the judicial power. Thereby, pardon granting turns into an effort of correction to a court decision, particularly in its implementation.

During the middle ages, the power to grant Pardon (clemency) in the European countries was held by various bodies, including Roman Catholic Churches and particular local authorities, but during the sixteenth century, this power was commonly concentrated in the hands of the king. During the Post-Reformation era in the United Kingdom, the kingdom's prerogative rights as "the king/queen's kindness" were used for three main purposes:

a. As an introduction to a not yet acknowledged self-defense, lunacy, and minority;

b. To develop a new method to deal with the enactors not yet acknowledged by the laws; and

c. To delete or disqualify a criminal charge. 
In Indonesia, provisions on pardon application procedure have been available since the Dutch colonial era. They were provided in separate legislation, namely Gratieregeling, contained in Staatsblad 1933 Number 22. During the Japanese colonial era, provisions on pardon granting were only available for the decisions passed by a regular (civil) court. After Indonesia's independence, there is a provision on pardon granting in Article 14 Paragraph (1) of the 1945 Constitution, determining that pardon, amnesty, abolition, and rehabilitation shall be granted by the President.

Pardon is a long-known term in Indonesia and has been expressly set out in Article 14 of the 1945 Constitution as the Indonesian constitution stipulated by its founders on 18 August 1945. This term pardon etymologically originates from the Dutch word "gratie" and the English word "granted", which means "sentence reduction" granted by the head of state (President) to a convict.

Pardon is President's judicial authority to reinstate justice relating to a court decision through sentence reduction, clemency granting, or charge deletion. The general principles of pardon are, among others, as follows:

a. Pardon is a Convict Right. Principally, a pardon application is a right given by the law to a convict to request clemency to the President.

b. Pardon may only be applied for "Penalty decisions which have obtained permanent legal force". Defined as "Court decisions which have obtained permanent legal force", are: 1) First instance Court Decision not being filed for appeal or appeal to the Supreme Court within the time frame determined by the Criminal Procedure Code; 2) Appeal court decision not being filed for an appeal to the Supreme Court within the time frame determined by the Criminal Procedure Code; 3) Appeal decision at the Supreme Court.

c. Pardon may only be applied for particular penalty decisions. Those particular penalty decisions shall be limited only to: 1) Death penalty decision; 2) Lifetime penalty decision; and 3) Imprisonment penalty decision for a minimum of 2 (two) years.

d. Pardon may only be applied once if the application is granted by the President.

e. Pardon application shall not postpone the execution of any decisions, other than death penalty.

f. The President has the authority to grant or refuse a pardon following a legal consideration from the Supreme Court.

Pardon granting power exists in the constitutions of almost all countries in the world; therefore it becomes part of a modern political feature. The question raised in this research is whether or not pardon granting in Indonesia and some countries in the world is the prerogative right of the president as the head of state.

\section{Research Method}

This research applies the normative legal research method. Marzuki said that legal research is a process to find legal rules, legal principles, and legal doctrines to address the legal issues faced [3]. The approaches used are conceptual and comparative. The conceptual approach is used to see the concept of the president's prerogative right in line with the adhered constitutionalism and state of law concepts, while the comparative approach is used to see the history as well as the application of prerogative rights in some countries. 


\section{Results and Discussion}

\subsection{Pardon as Prerogative Right in a Number of Countries}

According to Black's Law Dictionary, a pardon is an executive action alleviating or stipulating a penalty for a crime. It is a mercy from the authority alleviating a penalty of an offense and recovering the lost rights and privileges as the consequences thereof. Pardon is an action taken by the president in granting clemency to a person by way of amending, deleting, or reducing the penalty given by the judge. In the legal context, amnesty can be in the form of a government official's action of downgrading a criminal act.

The practice of pardon was first found in the United Kingdom. At that time, a king had a prerogative right called a gift from the king (vorstelijk gunst) to forgive almost all forms of crime committed by a person in opposition to the kingdom. This clemency is defined as the king's affectionate nature. Thereby, since the beginning of its emergence, a pardon has indeed become the king's prerogative right that shows his special nature. As time passes, the power to forgive as part of the process requires rechecking on the judicial system that is often considered unfair. Unfair penalties can be moderated through pardon granting by the Executives [4].

The authority to grant clemency or pardon is often included in the scope of the king or president's prerogative rights. The term prerogative rights originated from the Latin words praerogativa (chosen to vote first), praerogativus (asked to vote first), praerogare (asked before others), and the German word Das Vorrecht (privilege). According to Azize [5], prerogative rights are power rights which application has no limitation and intervention. Wahjono [6] also said that the president's prerogative rights derived from special and independent rights. Hence, prerogative rights are the independent authorities owned by a President. Based on the above elaboration, the prerogative concept can be defined as a special feature owned by a particular independent and absolute institution in which authority is indefeasible by other institutions or branches of power. In the modern state government system, these rights are often owned by the heads of state, kings or presidents, and the heads of government in particular sectors determined in the constitution [7].

During the European dark ages, a king usually has absolute power; even a king may claim the country as his own. Such a statement illustrates that a king is the whole representation of the existence of a country. The absolute power indicating a king's special feature is called prerogative rights. Historically, prerogative rights as the special feature of a king were first applied in the United Kingdom government. These rights grant privileges to political authorities to make their own decisions, even sometimes without reasons other than their personal interests [8].

In the United Kingdom, the power to grant clemency to criminals is a privilege owned by a king, where he is capable of reducing any penalty that has been decided on a person. In its early implementation, there is no limitation to the king's pardon granting power. However, in its development, particularly during the reign of King Charles II of 1660 to 1685, clemency may be granted to all forms of crime, other than impeachment [9].

Different from the United Kingdom, in the United States of America at the end of the $18^{\text {th }}$ century, when the legal apparatus was developed for its constitutional interest, the constitutional drafters did not include provisions on the president's authority to grant pardon in the Constitution. This was triggered by the great number of people rejecting the rule, as they thought it would be a big mistake if pardon granting authority was given only to one branch of power. That reason was based upon the American condition at that time under the reign of George III, 
which was considered a tyranny, resulting in fear that such power would provide legitimation to his government [9].

\subsection{Pardon in the Constitutions of Various Countries}

The power to forgive crime actors has become the privilege of almost all authorities worldwide since ancient times. According to Moore [10], a pardon is a legal action of the executives to entirely or partially release the legal consequence of a guilty verdict on the criminal act committed by a person. In a modern democracy, the power to grant clemency lies in the hands of their executive heads. The Kings of the United Kingdom have been applying the power to forgive for centuries. This power had not been written in its legal code until the seventh century. As time passes, the authority to forgive is practiced as a form of supervision on the development of the judicial system that is often known as mean and unforgiving. The penalties considered unfair or unjust may be moderated through pardon granting by the Executives [4].

In some countries, the president's power to grant clemency to crime actors comes in various names, such as "the right to grant clemency", prerogative of mercy and amnesty granting, pardon right, power of mercy, power to consent, and clemency granting. Despite the various terms used, they have the same meaning, namely a branch of the president's power to forgive the crime actors. Though clemency is a king's right of kindness, in its implementation and technically, it is not always directly granted by the president or king. In Canada, for example, a pardon is granted by the Governor General of Canada or a Council Governor (Federal Cabinet) as a prerogative right. An application for pardon is filed to the National Council for Conditional Release.

Countries like Brazil use the term exclusive power. In Algeria, the constitution states that the president has the power and right to grant pardon and reduce or alleviate penalty. Rwanda states that the president has the authority to use prerogative right following the procedure stipulated by the law and after consultation with the Supreme Court. Besides those countries, Bangladesh, Brunei Darussalam, Jordan, Denmark, and Chile, the authority to grant clemency is also explicitly called the prerogative right of the head of state (king or president). A number of countries use the term prerogative of mercy, while some others use the term president's special attribution (Chile). These terms actually have the same meaning, substantially understood as clemency.

\section{Conclusion}

Based on the constitutions of a number of countries in the world, we may conclude that the authority to forgive through pardon granting mechanism is a substance of the constitutions of most countries in the world. In these countries, the head of state's pardon granting power is explicitly called prerogative right, though the involvement of other branches of power remains possible in its mechanism. A number of state constitutional norms have also been examined and they normatively mention the involvement of other branches of power in the application of pardon authority through the use of various terms such as recommendation, hearing, information, consultation, advice, adjustment, concurrence, and others. Similar is the case in Indonesia, where the state administrative norms also state that the president shall grant pardon and rehabilitation by consistently observing the Supreme Court. 


\section{References}

[1] H. R. Ridwan, "Hukum administrasi negara," 2020.

[2] M. Susanto, "Perkembangan Pemaknaan Hak Prerogatif Presiden," J. Yudisial, vol. 9, no. 3, pp. 237-258, 2016.

[3] P. M. Marzuki, "Metode Penelitian Hukum,” Jakarta, Kencana, 2005.

[4] J. C. Baumgartner and M. H. Morris, "Presidential Power Unbound: A Comparative Look at Presidential Pardon Power," Polit. Policy, vol. 29, no. 2, pp. 209-236, 2001.

[5] J. Azize, "The Prerogative of Mercy in NSW," Pub. Sp. JL Soc. Just., vol. 1, p. 1, 2007.

[6] P. Wahyono, "Negara Republik Indonesia." Rajawali Press, Jakarta, 1986.

[7] S. Yuspitasari, "Sistem Multipartai di Era Pemerintahan Susilo Bambang Yudhoyono 20042009," dalam J. Din. Polit., vol. 1, no. 1, pp. 1470-2302.

[8] H. F. Isnaeni, "That's President's Prerogative Rights to Rule, not Me," FIGUR Magazine, 2007.

[9] History King, "History of Presidential Pardon," History King. [Online]. Available: http://www.historyking.com/miscellaneous/History-of-Presidential-Pardon.html.

[10] K. D. Moore, Pardons: Justice, mercy, and the public interest. Oxford University Press, 1997. 